\title{
A Simple Spectrophotometric Assay of Carboxypeptidase N (Kininase I) in Human Serum
}

\author{
By H. Schweisfurth ${ }^{1}$ ), E. Reinhart, J. Heinrich and E. Brugger \\ Department of Internal Medicine, University of Würzburg, Federal Republic of Germany
}

(Received February 4/April 26, 1983)

Summary: Kininase $I$ (carboxypeptidase $N$; EC 3.4.17.3) consists of carboxypeptidase $\mathrm{N}_{1}\left(\mathrm{CN}_{1}\right)^{\text {) and carboxy- }}$ peptidase $\mathrm{N}_{2}\left(\mathrm{CN}_{2}\right)$; these two enzymes can be differentiated by their activities towards hippuryl- $L$-arginine and hippuryl- $L$-lysine, respectively. A spectrophotometric assay for both carboxypeptidases in human serum is described and the biochemical behaviour of these enzymes investigated. The pH optima are found to be 8.4 for $\mathrm{CN}_{1}$ and $\mathrm{CN}_{2}$. The Michaelis-Menten constants are: $\mathrm{CN}_{1} 4.59 \pm 0.03 \mathrm{mmol} / \mathrm{l} ; \mathrm{CN}_{2} 37.26 \pm 3.49 \mathrm{mmol} / 1$. $\mathrm{CN}_{2}$ can be inhibited by EDTA (76\%), dimercaprolum (97\%) and phenanthroline (98\%). Diisopropylfluorophosphate has no influence on both enzymes. Elevated haemoglobin only interferes with $\mathrm{CN}_{1}$ measurements, and high bilirubin concentrations slightly alter the activity of both enzymes. High $\mathrm{CN}_{1}$ activities were found in sera of patients with sarcoidosis, and elevated $\mathrm{CN}_{2}$ activities were found in lung cancer.

Eine einfache spektralphotometrische Methode zur Bestimmung der Carboxypeptidase $N$ (Kininase I) im menschlichen Serum

Zusammenfassung: Die Carboxypeptidase N (CN; EC 3.4.17.3), auch Kininase I genannt, läßt sich aufgrund ihres unterschiedlichen biologischen Verhaltens in $\mathrm{CN}_{1}$ mit Hippuryl- $L$-arginin und $C_{2}$ mit Hippuryl- $L$ lysin als Enzymsubstrat unterscheideñ. Beide im Serum enthaltenen Enzyme spalten die terminalen Aminosäuren ab und lassen dadurch Hippursäure entstehen, deren Konzentration spektralphotometrisch gemessen wird. $\mathrm{CN}_{1}$ und $\mathrm{CN}_{2}$ wurden biochemisch charakterisiert. Das pH Optimum lag bei 8,4. Die Michaelis-MentenKonstante betrug: $\mathrm{CN}_{1} 4,59 \pm 0,03 \mathrm{mmol} / 1, \mathrm{CN}_{2} 37,29 \pm 3,49 \mathrm{mmol} / 1 . \mathrm{CN}_{2}$ wurde zu $76 \%$ durch EDTA, Dimercaprol (97\%) und Phenanthrolin (98\%) inhibiert. Diisopropylfluorophosphat hatte keinen Einfluß auf beide Enzyme. Erhöhtes Hämoglobin interferierte bei der $\mathrm{CN}_{1}$, Bilirubin zeigte nur eine geringe Interferenz. Klinische Bedeutung scheint dẹr $\mathrm{CN}_{1}$ bei der Lungensarkoidose zuzukommen, bei der die höchsten Aktivitäten im Gegensatz zu anderen Lụngenerkrankungen gefundèn wurden. Beim Lungenkarzinom war $\mathrm{CN}_{2}$ erhöht.

\section{Introduction}

An enzyme capable of rapidly releasing carboxylterminal lysine and arginine from peptides has been found in the bovine pancreas (1). This enzyme was named carboxypeptidase B (EC 3.4.17.3) or basic carboxypeptidase and was also purified (2) and characterized $(3,4)$. Other tissues also have carboxypeptidase $B$ activity $(5,6)$. In human plasma, carboxy-

\footnotetext{
1) Supported by Deutsche Forschungsgemeinschaft (Schw 309/ 2-1)
}

peptidase B-like activity was found, which differs from the isolated pancreas enzyme in molecular weight, the velocity of hydrolysis of lysine-containing substrates compared to arginine-containing substrates, and inhibition patterns (7). Additionally, it inactivates the nonapeptide bradykinin by removing the C-terminal arginine; therefore it is also called kininase I. In human plasma, carboxypeptidase $\mathbf{N}$ has a molecular weight of 280000 . Left standing it dissociates to subunits of 45000 and 90000 (8). The plasma enzyme activity was low in some diseases of

J. Clin. Chem. Clin. Biochem. / Vol. 21, 1983 / No. 10 
the liver, which indicate that the liver and not the pancreas is the site of enzyme synthesis. The physiological and pathophysiological role of this aminopeptidase in human body fluid has not yet been thoroughly clarified. One reason for the lack of interest in this enzyme may be that the known methods are not routinely practiced in clinical laboratories. Therefore we developed a simple spectrophotometric method for the determination of this carboxypeptidase. This assay is based on the estimation of hippuric acid formed by carboxypeptidase $\mathrm{N}$ from two synthetic substrates.

Carboxypeptidase $\mathrm{N}_{1}\left(\mathrm{CN}_{1}\right)$ cleaves the synthetic substrate hippuryl- $L$-arginine, while carboxypeptidase $\mathrm{N}_{2}\left(\mathrm{CN}_{2}\right)$ is used for splitting the hippuryl- $L$-lysine. After biochemical characterisation of both enzymes, this method was applied to a large number of untreated sera in various lung diseases.

\section{Materials and Methods}

Reagents

Hippuric acid, hippuryl- $L$-arginine, hippuryl- $L$-lysine, diisopropylfluorophosphate, ethylenediaminetetra-acetic acid (EDTA), dimercaprolum, phenanthroline, bilirubin and haemoglobin were purchased from Sigma, Munich.

All other chemicals of high purity were obtained from Merck, Darmstadt. Test tubes were from Sarstedt, Stuttgart. In all assays distilled and deionized water was used.

$0.05 \mathrm{~mol} / 1$ hippuryl- $L$-arginine solution, molecular weight 335.4 , was prepared by dissolving $167.7 \mathrm{mg}$ hippuryl- $L$-arginine in $10 \mathrm{ml}$ of $0.5 \mathrm{~mol} / 1$ potassium phosphate buffer, $\mathrm{pH} 8.4 ; 0.1 \mathrm{~mol} / \mathrm{h}$ hippuryl- $L$-lysine solution, molecular weight 307.3 , was mixed by dissolving $307.3 \mathrm{mg}$ hippuryl- $L$-lysine also in $10 \mathrm{ml}$ of the same buffer. The buffer was prepared by mixing solution $\mathrm{A}$ (containing $87 \mathrm{~g} / \mathrm{l}(0.5 \mathrm{~mol} / \mathrm{l}) \mathrm{K}_{2} \mathrm{HPO}_{4}$ and $\left.43.8 \mathrm{~g} /(0.75 \mathrm{~mol} / \mathrm{l}) \mathrm{NaCl}\right)$ and solution $\mathrm{B}$ (containing $68.0 \mathrm{~g} / \mathrm{/}(0.5 \mathrm{~mol} / \mathrm{l}) \mathrm{KH}_{2} \mathrm{PO}_{4}$ and $43.8 \mathrm{~g} / \mathrm{l}$ $(0.75 \mathrm{~mol} / \mathrm{l}) \mathrm{NaCl})$. A sufficient quantity of solution $B$ was added to $100 \mathrm{ml}$ of solution $\mathrm{A}$ to achieve a $\mathrm{pH}$ of 8.4 at $20^{\circ} \mathrm{C}$.

The buffer was stored at $4^{\circ} \mathrm{C}$, which caused some precipitation, but the precipitate redissolved at $20^{\circ} \mathrm{C}$

Serum samples

Blood was collected from healthy controls and from patients with various diseases under the following conditions: Arm venipuncture was performed at $7.30 \mathrm{a} . \mathrm{m}$. after fasting for $2 \mathrm{~h}$ and bed rest, with no administration of drugs during the preceding $24 \mathrm{~h}$. The healthy donors had $1 / 2 \mathrm{~h}$ bed rest. The blood was allowed to clot in a $10 \mathrm{ml}$ polypropylene test tube. Blood was centrifugated for $10 \mathrm{~min}$ at $1200 \mathrm{~g}$ in a Heraeus cryofuge at $4^{\circ} \mathrm{C}$, and the supernatant was carefully removed and stored at $-20^{\circ} \mathrm{C}$ until assay.

\section{Incubation procedure}

$50 \mu \mathrm{l}$ serum for measurement of $\mathrm{CN}_{1}$, or $25 \mu \mathrm{l}$ serum for $\mathrm{CN}_{2}$, was added to $200 \mu \mathrm{l}$ of substrate buffer solution containing hippuryl$L$-arginine or hippuryl- $L$-lysine in duplicated $4 \mathrm{ml}$ polypropylene test tubes, tightly covered, vortexed for $15 \mathrm{~s}$ and incubated for $60 \mathrm{~min}$ at $37^{\circ} \mathrm{C}$ in a temperature controlled shaker water bath. The enzymatic reaction was stopped by addition of $250 \mu \mathrm{l}$ of 1 $\mathrm{mol} / \mathrm{HCl}$ solution and vortexed for $15 \mathrm{~s}$. The blanks were sim- ilary treated except that after addition of serum the enzymatic reaction was stopped at once by $250 \mu \mathrm{l}$ of $1 \mathrm{~mol} / \mathrm{HCl}$ before in cubation.

All samples were removed from the water bath and placed in crushed ice for $5 \mathrm{~min}$. Afterwards, $1500 \mu \mathrm{l}$ ethyl acetate were added, vortexed for $30 \mathrm{~s}$ and centrifuged for $10 \mathrm{~min}$ at $4000 \mathrm{~g}$. $1 \mathrm{ml}$ of the upper layer (ethyl acatate) was pipetted into a $4 \mathrm{ml}$ test tube and placed in a boiling water bath for $45-60 \mathrm{~min}$ to evaporate the ethyl acetate thoroughly. $3 \mathrm{ml}$ of $1 \mathrm{~mol} / 1 \mathrm{NaCl}$ solution was added to each tube and vortexed for $30 \mathrm{~s}$. All samples were placed in a water bath at $70^{\circ} \mathrm{C}$ for $5 \mathrm{~min}$ to redissolve all the residual hippuric acid, then vortexed for $30 \mathrm{~s}$. After $15 \mathrm{~min}$ standing at room temperature, the absorbance of the hippuric acid was read in a $1-\mathrm{cm}$ rectangular cuvette at $228 \mathrm{~nm}$ in a Hitachi precision spectralphotometer $100-40$, with distilled deionized water as a blank.

As internal standard serum, a pool serum of normal persons was used.

\section{Calculation of catalytic activity}

1 Unit (U) of carboxypeptidase $\mathrm{N}$ activity is defined as the amount of enzyme required to release $1 \mu \mathrm{mol}$ hippuric acid per min at $37^{\circ} \mathrm{C}$ under standard assay conditions in $1 \mathrm{ml}$ serum (i. e., $\mathrm{U} / \mathrm{ml}=\mathrm{kU} / \mathrm{l}=\mu \mathrm{mol} / \mathrm{ml} \cdot \mathrm{min})$.

$$
\begin{aligned}
& 1 \mathrm{U} / \mathrm{l}=\frac{\mathrm{A}_{228} \times 10^{5} \times 3}{980 \times 0.91 \times 0.67 \times 60 \times \mathrm{V}_{\bar{n}}} \text { or } \begin{array}{l}
\mathrm{A}_{228} \times 167.36 \text { for } \mathrm{CN}_{1} \\
\mathrm{~A}_{228} \times 334.72 \text { for } \mathrm{CN}_{2}
\end{array} \\
& A_{228}=\frac{\text { Absorbance sample }_{1}+\text { Absorbance sample }}{2} \\
& \text { 1- Absorbance blank }
\end{aligned}
$$

$980 \mathrm{~m}^{2} \times \mathrm{mol}^{-1} \quad \varepsilon_{228}$ hippuric acid

0.91 fraction of extracted hippuric acid

0.67 fraction of sampled ethyl acetate

60 incubation time in $\mathrm{min}$

$\mathrm{V}_{\mathrm{n}} \quad \mathrm{V}_{\mathrm{CN} \mathrm{I}}=0.050 \mathrm{ml}$ serüm for $\mathrm{CN}_{1}$

$\mathrm{V}_{\mathrm{CN} 2}=0.025 \mathrm{ml}$ serum for $\mathrm{CN}_{2}$

$10^{5} \quad$ conversion to liter

Statistical calculations were performed with Student's t-test. For correlation Spearman rank test was used.

Additionally, routine laboratory parameters were evaluated from the same serum samples used for enzymatic measurements.

\section{Results}

Since samples are stored in crushed ice before incubation, there is a time lag before the incubation mixture attains $37^{\circ} \mathrm{C}$. For this reason the course of reaction of the carboxypeptidases did not achieve linearity until after $10-20 \mathrm{~min}$, using hippuryl- $L$-arginine or hippuryl- $L$-lysine as synthetic substrates. The reaction was still linear up to $120 \mathrm{~min}$ (fig. 1). In our routine assay we used an incubation time of $60 \mathrm{~min}$, which clearly guarantees linearity.

The $\mathrm{pH}$-dependence of $\mathrm{CN}_{1}$ and $\mathrm{CN}_{2}$ was investigated, using potassium phosphate buffer. In repeated assays $\mathrm{CN}_{1}$ showed a small peak of activity at $\mathrm{pH} 8.4$ (fig. 2). For $\mathrm{CN}_{2}$ a broad $\mathrm{pH}$ optimum was found between 8.2 and 8.6. In subsequent enzymatic reactions, we also used $\mathrm{pH} 8.4$ for $\mathrm{CN}_{2}$. 

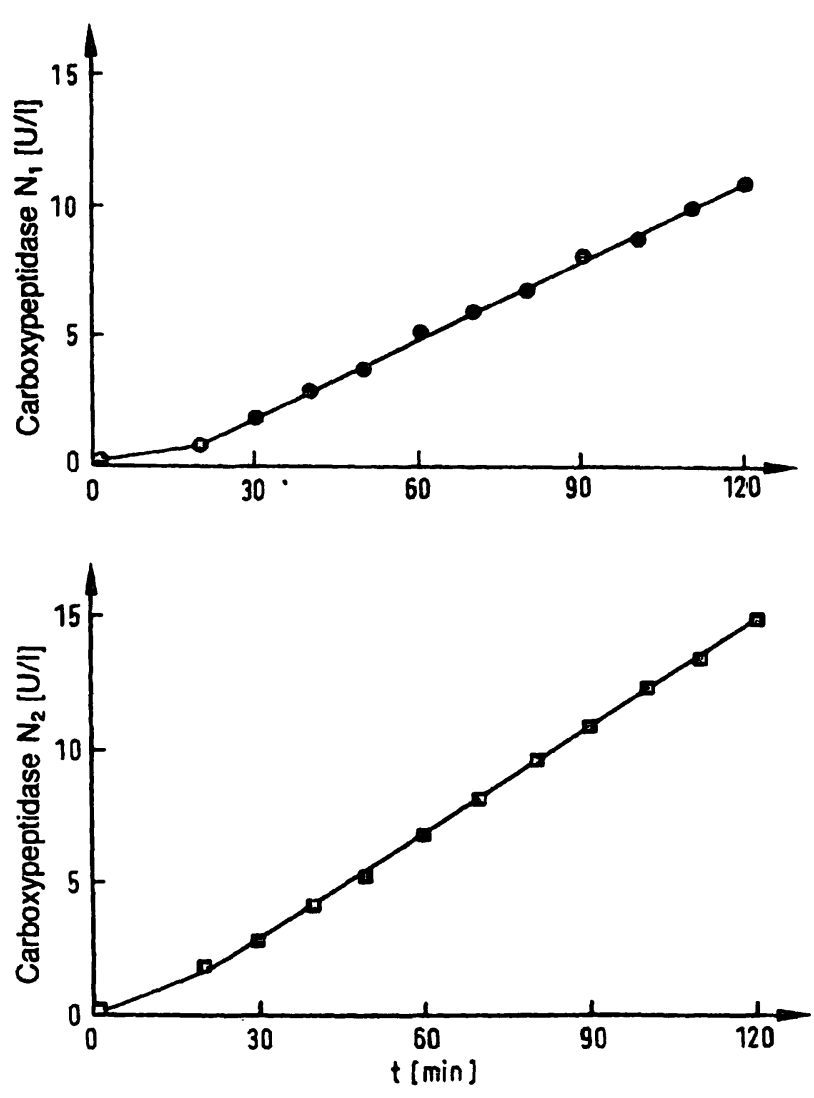

Fig. 1. Effect of incubation time on carboxypeptidase $N_{1}$ catalytic activity concentration (-) and on carboxypeptidase $\mathrm{N}_{2}$ catalytic activity concentration (⿴囗十) in serum.

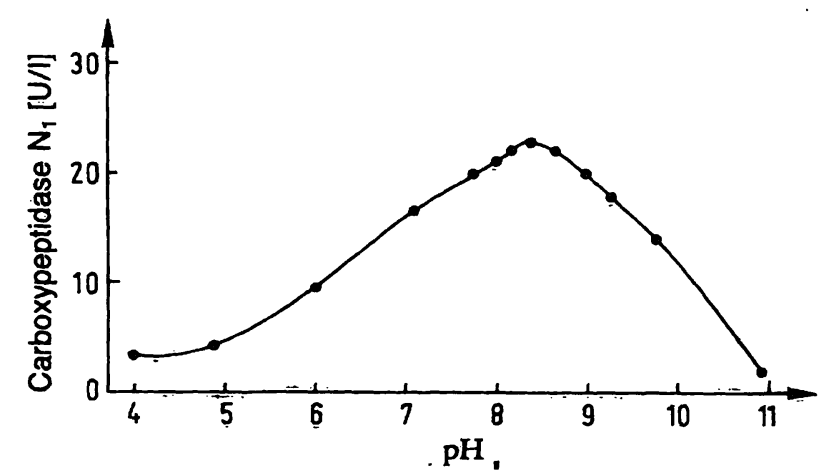

Fig. 2. Effect of $\mathrm{pH}$ on carboxypeptidase $\mathrm{N}_{1}$ catalytic activity concentration in serum, measured as the rate of hydrolysis of hippuryl- $L$-arginine.

Linearity of the assay could also be proven by serum dilution (fig. 3). $\mathrm{CN}$ activity was plotted as dilution factor. The linear regression analysis gave $\left(\mathrm{CN}_{1} \mathrm{r}=\right.$ $0.99, \mathrm{CN}_{2} \mathrm{r}=0.98$ ).

To investigate the dependence of catalytic activity on the incubation temperature, incubations were performed between $+2^{\circ} \mathrm{C}$ and $+63^{\circ} \mathrm{C}$ in a heated water bath. $\mathrm{CN}_{1}$ showed highest activity at $40^{\circ} \mathrm{C}, \mathrm{CN}_{2}$ at $41^{\circ} \mathrm{C}$ (fig. 5).
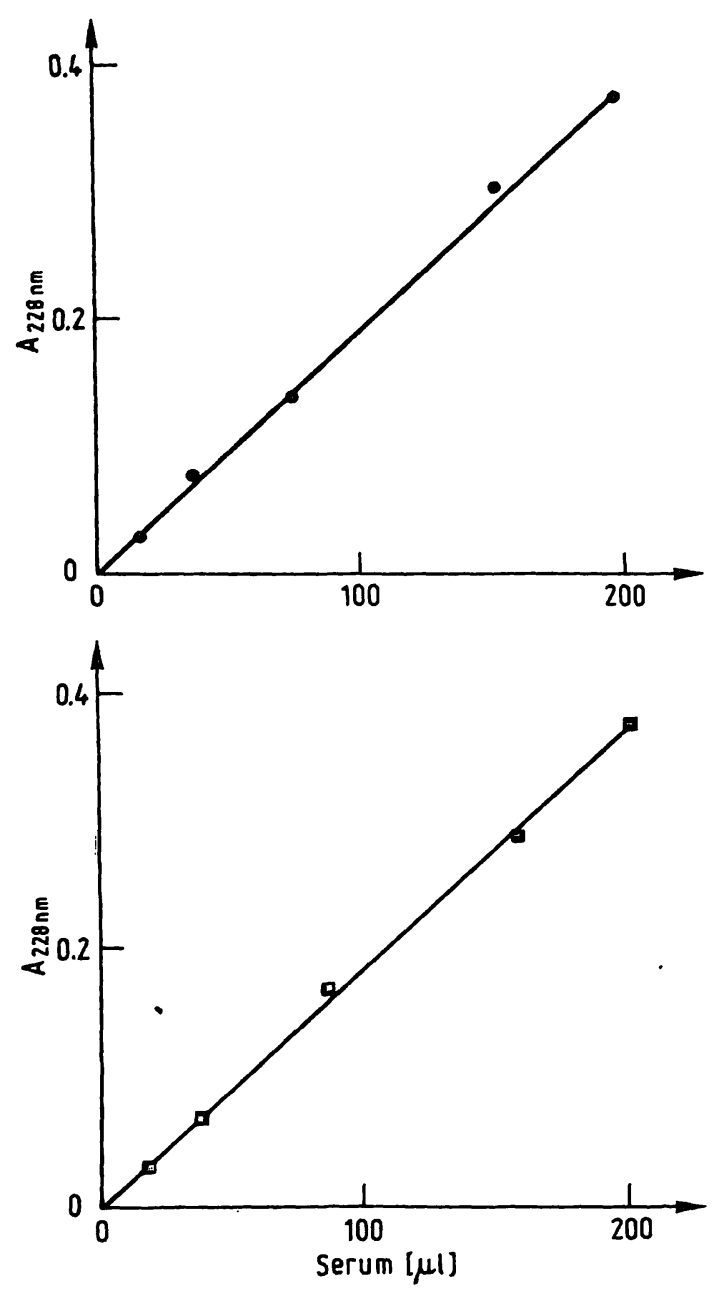

Fig. 3. Relationship between carboxypeptidase $\mathrm{N}_{1}(\mathrm{O}-\mathbf{O})$ and carboxypeptidase $\mathrm{N}_{2}$ catalytic activity concentrations (口_

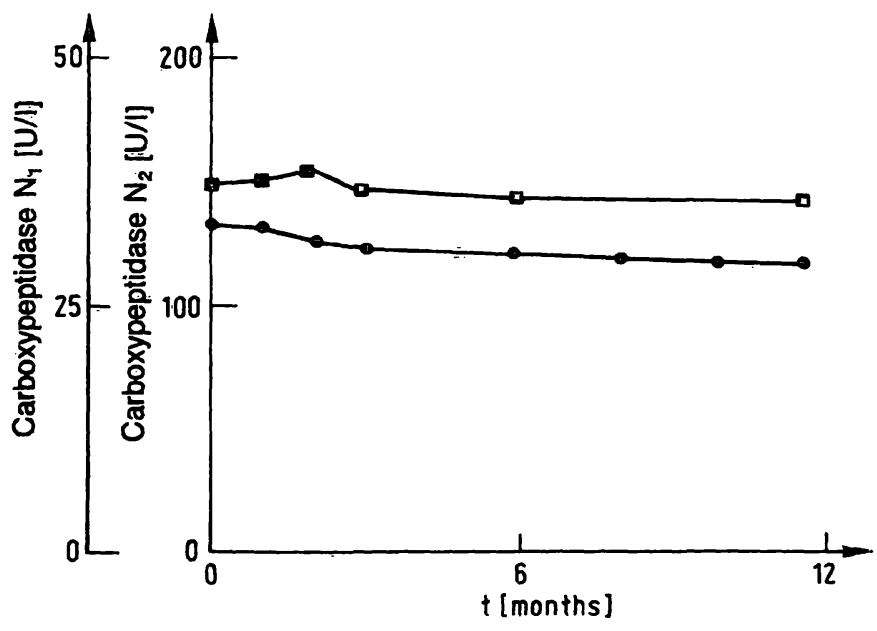

Fig. 4. Stability of carboxypeptidase $\mathrm{N}_{1}(--0)$ and carboxypeptidase $\mathrm{N}_{2}$ (国- a catalytic activity concentration in serum stored at $-20^{\circ} \mathrm{C}$ during 12 months.

The stability of $\mathrm{CN}_{1}$ and $\mathrm{CN}_{2}$ was tested during storage at $-20^{\circ} \mathrm{C}$ for up to 12 months. Only slight decreases of $\mathrm{CN}_{1}(9.3 \%)$ and $\mathrm{CN}_{2}(5.3 \%)$ were observed (fig. 4). 

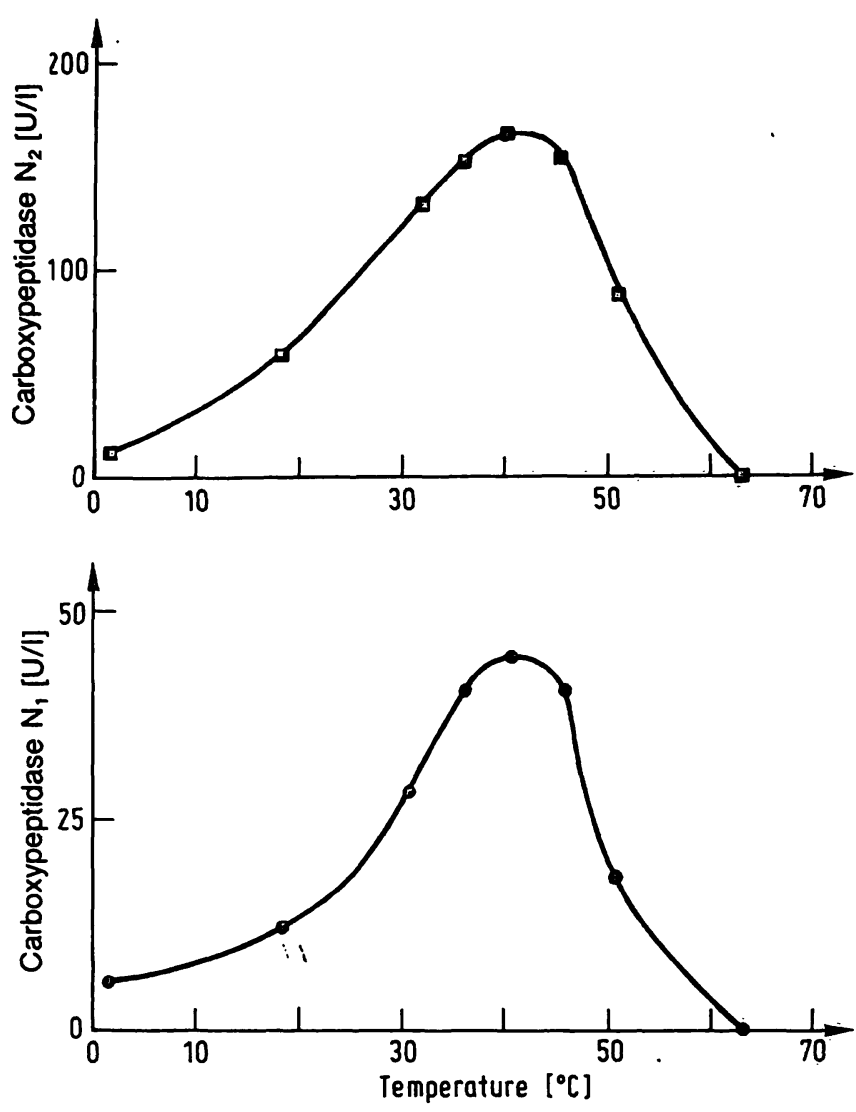

Fig. 5. Effect of incubation temperature on carboxypeptidase $N_{1}$ (O-O) and carboxypeptidase $\mathrm{N}_{2}(\mathbf{O}-\mathbf{R})$ catalytic activity concentrations in serum, measured under the assay conditions described in text.

Michaelis Menten constants $\left(K_{\mathrm{m}}\right)$ were determined by the Linewater Burk plot. The following $K_{\mathrm{m}}$ values were found.

$\mathrm{CN}_{1}: 4.59 \pm 0.03(\mathrm{SD}) \mathrm{mmol} / \mathrm{l},(\mathrm{n}=4)$,

$$
\mathrm{V}_{\max } 19.11 \pm 5.68 \mu \mathrm{mol} / 1 \cdot \min
$$

$\mathrm{CN}_{2}: 37.29 \pm 3.49 \mathrm{mmol} / \mathrm{l},(\mathrm{n}=3)$,

$$
\mathrm{V}_{\max } 147.82 \pm 32.21 \mu \mathrm{mol} / \mathrm{l} \cdot \mathrm{min} \text {. }
$$

Thus, the affinity of $\mathrm{CN}_{1}$ for hippuryl- $L$-arginine is greater than the affinity of $\mathrm{CN}_{2}$ for hippuryl- $L$-lysine.

Blocking agents were also tested (tab. 1). EDTA inhibits only $\mathrm{CN}_{2}(76 \%)$ and shows no inhibition of $\mathrm{CN}_{1}$.

$\mathrm{CN}_{2}$ could be nearly totally blocked by dimercaprolum $(97 \%)$, but $\mathrm{CN}_{1}$ was inhibited by only $54 \%$. Similiar results were obtained for inhibition by phen-
Tab. 1. Inhibitor concentrations necessary to produce $50 \%$ inhibition $\left(\mathrm{I}_{50}\right)$ of carboxypeptidase $\mathrm{N}_{1}\left(\mathrm{CN}_{1}\right)$ and $\mathrm{N}_{2}\left(\mathrm{CN}_{2}\right)$ measured under standard assay conditions described in the text.

\begin{tabular}{lll}
\hline & \multicolumn{2}{l}{$\mathrm{I}_{50}(\mathrm{mmol} / \mathrm{l})$} \\
Blocking agent & $\mathrm{CN}_{1}$ & $\mathrm{CN}_{2}$ \\
\hline Diisopropylfluorophosphate & none & none \\
EDTA & none & 3.16 \\
Phenanthroline & 0.59 & 0.15 \\
Dimercaprolum & 9.70 & 2.41 \\
\hline
\end{tabular}

anthroline: $\mathrm{CN}_{1}(64 \%), \mathrm{CN}_{2}$ (98\%). Diisopropylfluorophosphate had no inhibitory effect on $\mathrm{CN}_{1}$ or $\mathrm{CN}_{2}$ activity, but the curves suggest a slight activa= tion of both enzyymes.

The interference of bilirubin and haemoglobin was also tested. Initially bilirubin reduced carboxypeptidase activity slightly. Only $\mathrm{CN}_{1}$ activity was decreased by addition of haemoglobin.

For the precision of these methods see table 2.

We measured $\mathrm{CN}_{1}$ and $\mathrm{CN}_{2}$ in healthy controls and in patients with various lung diseases (tab. 3 ). No positive correlation could be found in 47 normal subjects between cholesterol $\left(\mathrm{CN}_{1}: \mathrm{r} \cong 0.04 ; \mathrm{CN}_{2} \mathrm{r}\right.$ $=0.08)$ and triglycerides $\left(\mathrm{CN}_{1}: \mathrm{r}=0.01 ; \mathrm{CN}_{2} \mathrm{r}=\right.$ 0.10). Significantly elevated activities of $\mathrm{CN}_{1}$ were found in sera of patients with sarcoidosis $(p<0.0001)$ compared with the healthy controls and with lung cancer patients $(\mathrm{p}<0.002) . \mathrm{CN}_{2}$ was significantly increased in patients with lung cancer $(p<0.0001)$ compared with controls and with sarcoidosis patients $(\mathrm{p}<0.02)$.

\section{Discussion}

Our interest in carboxypeptidase was prompted by our studies of the angiotensin-I-converting enzyme in lung diseases. Angiotensin-I-converting enzymè was found to be elevated in sarcoidosis (9) and liver diseases (10). Similar behaviour by other carboxypeptidases in human blood was expected.

The method described here for the determination of $\mathrm{CN}_{1}$ and $\mathrm{CN}_{2}$ activity in sẹrum by spectrophotomet-

\begin{tabular}{|c|c|c|c|c|c|c|}
\hline \multirow{2}{*}{ " } & \multicolumn{3}{|c|}{ Carboxypeptidase $N_{1}(U / 1)$} & \multicolumn{3}{|c|}{ Carboxypeptidase $\mathrm{N}_{2}(\mathrm{U} / \mathrm{l})$} \\
\hline & Mean & SD & $\mathrm{CV} \%$ & Mean & SD & $\mathrm{CV} \%$ \\
\hline Intraassay & 30.9 & \pm 0.6 & $1.8(n=16)$ & 155.8 & \pm 2.9 & $1.9(n=15)$ \\
\hline Interassay (day to day) & 30.3 & \pm 2.1 & $7.1(n=30)$ & 156.3 & \pm 5.1 & $3.3(n=28)$ \\
\hline
\end{tabular}

Tab. 2. Precision data of assayed serum to estimate the variability (CV \%) of the method. 


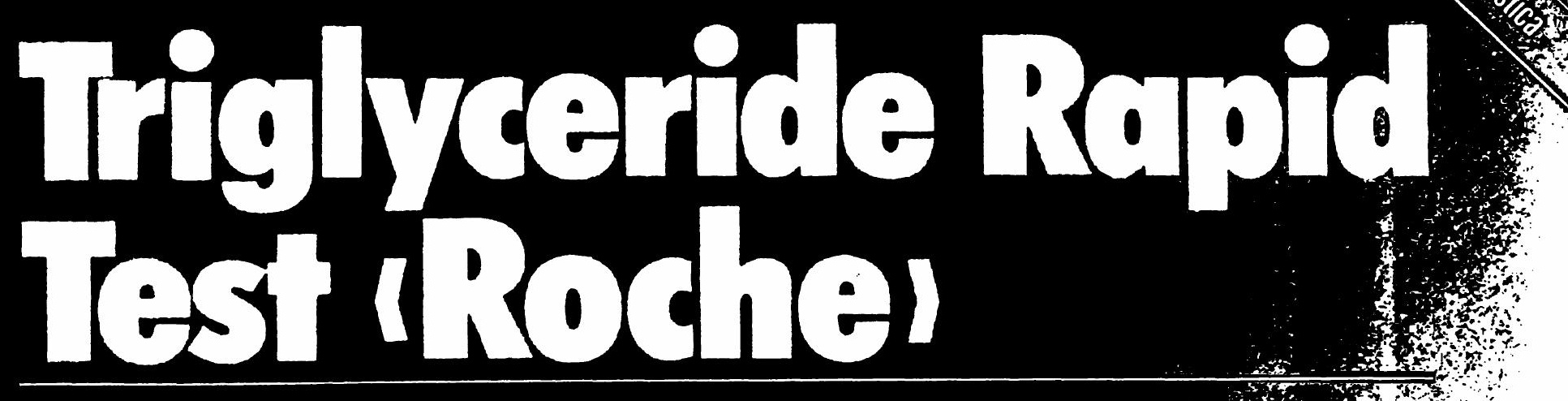

vollenzymatischer Test mit Trockengranulat iegigens $^{2}$

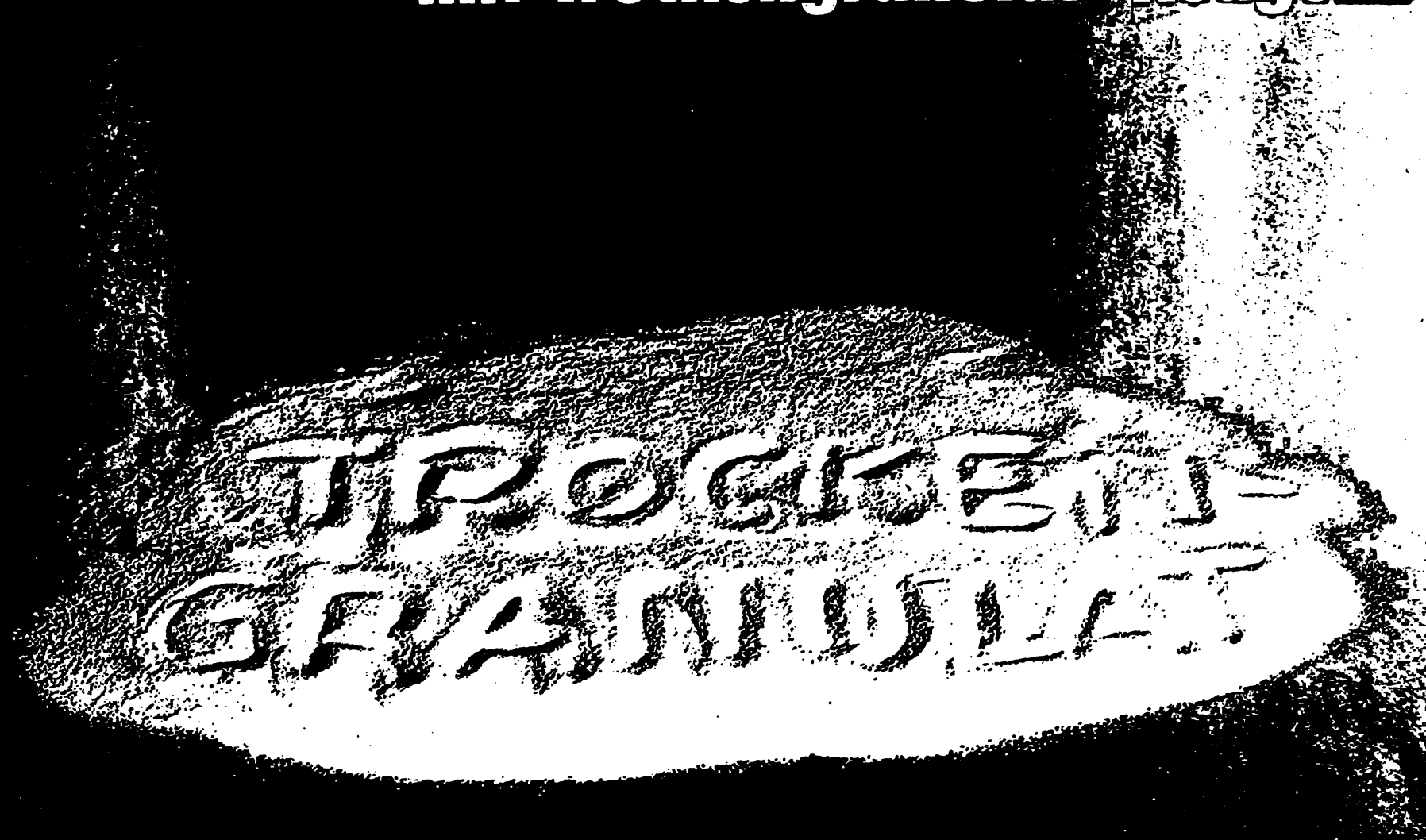

\section{Die bewährten} Vorzigie:

- Hohe Stabilität des Reagenz

- Einfache Handhabung (Monoreagenz und Glycerokinase)

- Erweiterter MeBbereich

- Geringe Chargenunterschiede

\section{Wirtschafilich durch Preis und Konfektionierung:}

- Reagenz in Granulatform für mechanisierte Analyse und Serienbestimmungen

Testpackungen: Artikel Nr. 1070 (Granulatreagenz $14 \times 50 \mathrm{ml}$ ) Artikel Nr. 1086 (Granulatreagenz $14 \times 20 \mathrm{ml}$ ) 


\section{Walter de Gruyter Berlin. New York}

\section{J. Büttner}

(Editor)

\section{History of Clinical Chemistry}

$1983.18 \mathrm{~cm} \times 26 \mathrm{~cm} .91$ pages with illussträtions. Hardcover. DM 98,-; approx. US \$44.75 ISBN 3110089122

Clinical Chemistry is a special discipline of medicine which; due to its close relationship both to medicine and to chemistiry, is of particular interest to the historian of science.

This "History of Clinical Chemistry" is based on a modern outlook on the history of science. Since the investigation of the history of clinical chemistry is still in progress, the book is divided into eight separate contributions, written primarily by histọrians of science, which together provide a good coverage of the history of Clinical Chemistry in the nineteenth century.

The book is written entirely in Engilish and will therefore appeal to an international readerșip. Each contribution is provided with numerous notes and references.

\section{Contents}

Johannes Büttner - Introduction - Nikolaus Mani - The historical background of Clinical Chemistry · Joseph SS. Fruton · Biochemistry and Clinical Chemistry. A retrospect - Erika Hickel . The emergence of Clinical Chemistry in the 19th century: Presuppositions and consequences "Johannes Büttnêr : Johann Joseph von Scherer (1814-1869). A commentary on the early history of Clinical Chemistry · Hans H. Simmer - Medicine and Chemistry around the middle of the 19th century in Erlangen: Eugen Franz Freiherr von Gorup-Besanez (1817-1878) · Johannes Büttner - Evolution of Clinicäl Enzymology · Johannes Büüttner . Relationships between Clinical Medicine and Clinical Chemistry, illustrated by the example of the German-speaking countries in the late 19th century - Wendell T. Caraway - Major developments in clinical chemical instrumentation. 
Tab. 3. Carboxypeptidase $N_{1}$ and $N_{2}$ catalytic concentrations in serum of patients with lung diseases compared with healthy controls. In sarcoidosis $\mathrm{CN}_{1}$ was significantly elevated $(p<0.002)$ and $\mathrm{CN}_{2}$ was reduced $(\mathrm{p}<0.02)$ compared with lung cancer.

\begin{tabular}{|c|c|c|c|c|c|c|}
\hline & \multicolumn{3}{|c|}{ Carboxypeptidase $\mathrm{N}_{1}(\mathrm{U} / \mathrm{l})$} & \multicolumn{3}{|c|}{ Carboxypeptidase $\mathrm{N}_{2}(\mathrm{U} / \mathrm{l})$} \\
\hline & & $\mathbf{n}$ & $\mathrm{p}<$ & & $\mathrm{n}$ & $\mathrm{p}<$ \\
\hline $\begin{array}{l}\text { Sarcoidosis } \\
\text { Lung tuberculosis } \\
\text { Lung cancer } \\
\text { Asthma } \\
\text { Pneumonia } \\
\text { Chronic bronchitis } \\
\text { Healthy controls }\end{array}$ & $\begin{array}{l}73.9 \pm 32.4 \\
37.8 \pm 15.7 \\
54.3 \pm 25.5 \\
39.5 \pm 12.7 \\
43.2 \pm 21.8 \\
50.1 \pm 17.5 \\
36.1 \pm 9.9\end{array}$ & $\begin{array}{r}40 \\
32 \\
54 \\
18 \\
9 \\
14 \\
47 \\
214\end{array}$ & $\begin{array}{l}0.0001 \\
0.50 \\
0.0001 \\
0.50 \\
0.20 \\
0.002\end{array}$ & $\begin{array}{l}177.1 \pm 41.8 \\
138.5 \pm 37.3 \\
195.3 \pm 38.4 \\
166.9 \pm 29.7 \\
174.0 \pm 43.6 \\
167.4 \pm 34.4 \\
144.2 \pm 26.0\end{array}$ & $\begin{array}{r}43 \\
33 \\
52 \\
26 \\
13 \\
20 \\
54 \\
241\end{array}$ & $\begin{array}{l}0.0001 \\
0.50 \\
0.0001 \\
0.001 \\
0.01 \\
0.01\end{array}$ \\
\hline
\end{tabular}

ric assessment of the cleavage of synthetic substrates, is accurate and simple to perform.

Previous reports showed that human serum $\mathrm{CN}$ could be separated by isoelectric focusing into two subunits (12). The subunits of $\mathrm{CN}$ could also be distinguished by immunological methods (13). It was speculated that $\mathrm{CN}$ consists of two species which were apparently isoenzymes (12).

With our method, which is derived from the spectrophotometric measurement of angiotensin-I-converting enzyme (9), we also found differences in biochemical behaviour between $\mathrm{CN}_{1}$ and $\mathrm{CN}_{2}$. The $\mathrm{pH}$ curve showed a broad $\mathrm{pH}$ optimum when using hippuryl- $L$-lysine as substrate. The $K_{\mathrm{m}}$-values indicate that the affinity of the enzyme activity to hippuryl- $L$ arginine is greater than to hippuryl- $L$-lysine. Only $\mathrm{CN}_{2}$ could be inhibited by EDTA, $\mathrm{CN}_{1}$ was not influenced by this chelating agent.

For comparison, the $K_{\mathrm{m}}$ of carboxypeptidase B, which cleaves the same substrates, is $0.21 \times 10^{-3}$ mol/1 for hippuryl- $L$-arginine and $7.7 \times 10^{-3} \mathrm{~mol} / 1$ for hippuryl- $L$-lysine (11). This shows that $C_{1}$ removes the $C$ terminal arginine faster than lysine. Pancreatic carboxypeptidase $B$ acts in the same way,

\section{References}

1. Folk, J. E. (1956) J. Am. Chem. Soc. 78, 3541.

2. Mariṇkovic, D. V., Marinkovic, J. N., Erdös, E. G. \& Robinson, C. J. (1977) Biochèm. J. 163, 253-260.

3. Folk, J. E., Piez, K.A., Carroll, W.R. \& Gladner, J.A. (1960) J. Biol. Chem. 235, 2272-2277.

4. Marinkovic, D. V. (1979) Biochem. Med. 22, 11-26.

5. Otto, K. \& Riesenkönig, H. (1975) Biochim. Biophys. Acta $379,462-475$.

6. Taylor, S. L. \& Tappel, A. L. (1974) Biochim. Biophys. Acta 341, 99-111.

7. Erdös, E. G. \& Sloane, E. M. (1962) Biochem. Pharmacol. $11,585-592$.

8. Oshima, G., Kato, J. \& Erdös, E. G. (1974) Biochim. Biophys. Acta 365, 344-348.

9. Lieberman, J. (1975) Am. J. Med. 59, 365-372. but the inhibition patterns show differences between carboxypeptidase $\mathrm{B}$ and $\mathrm{CN}$.

Previous studies, using hippuryl- $L$-lysine as enzyme substrate, describe normal values of carboxypeptidase $\mathbf{N}$ in pregnant women and in some patients with tumours. Reduced activity was found in patients with cirrhosis of the liver $(14,15)$, which indicate that this enzyme may be synthesized in liver tissue. This could result in a decreased inactivation of bradykinin and other vasodilatating peptides in liver diseases. We measured $\mathrm{CN}_{1}$ and $\mathrm{CN}_{2}$ in patients with lung diseases and found high activities of $\mathrm{CN}_{1}$ in sarcoidosis, and high activities of $\mathrm{CN}_{2}$ in lung cancer compared with healthy controls. Initial investigations indicate that the elevation of $\mathrm{CN}_{1}$ in sarcoidosis is a better parameter of clinical activity than angiotensin-I-converting enzyme. Like angiotensin-I-converting enzyme, the source of $\mathrm{CN}_{1}$ may be the epitheloid cells. There is some evidence that $\mathrm{CN}_{2}$ is produced by malignant tumour cells.

\section{Acknowledgements}

The authors wish to thank Mrs. Carmen Kneyer for her assistance in preparing the manuscript.

10. Schweisfurth, H. \& Wernze, H. (1979) Acta Hepato-Gastroenterol. 26, 207-210.

11. Wolff, E. C., Schirmer, E. W. \& Folk, J. E. (1962) J. Biol. Chem. 237, 3094-3099.

12. Koheil, A. \& Forstner, G. (1978) Biochim. Biophys. Acta $524,156-161$.

13. Levin, Y., Skidgel, R. A. \& Erdös, E. G. (1982) Proc. Natl. Acad. Sci. U.S.A. 79, 4618-4622.

14. Erdös, E. G., Wohler, I. M., Levine, M. I. \& Westerman, M. P. (1965) Clin. Chim. Acta 11, 39-43.

. 15. Schweisfurth, H. \& Burghardt, W. (1983) in press.

Dr. med. Hans Schweisfurth Medizinische Universitätsklinik Josef-Schneider-Straße 2 D-8700 Würzburg 
